\title{
ANALISIS PENDAPATAN NELAYAN PANCING ULUR DI KAMPUNG KARATUNG II KECAMATAN MANGANITU KABUPATEN KEPULAUAN SANGIHE
}

\author{
Income Analysis of Hand Line Fishermen in Karatung II Village Manganitu District \\ Sangihe Islands Regency
}

\author{
Costantein Imanuel Sarapil ${ }^{1)}$, Eunike Irene Kumaseh ${ }^{1)}$, Yafet Takasabare ${ }^{2)}$ \\ ${ }^{1}$ Dosen Program Studi Teknologi Penangkapan Ikan, Jurusan Perikanan dan Kebaharian, Politeknik Negeri Nusa Utara \\ ${ }^{2}$ Mahasiswa Program Studi Teknologi Penangkapan Ikan, Jurusan Perikanan dan Kebaharian, Politeknik Negeri Nusa Utara \\ Email: sarapilcostantein79@gmail.com
}

\begin{abstract}
Abstrak: Penelitian ini bertujuan untuk melihat besarnya pendapatan nelayan pancing ulur di Kampung Karatung II Kecamatan Manganitu Kabupaten Kepulauan Sangihe. Kampung Karatung II terletak di Kecamatan Manganitu dengan jumlah penduduk 991 jiwa. Pendapatan nelayan di Kampung Karatung II bergantung pada hasil tangkapan. Jenis ikan hasil tangkapan pada umunya yaitu ikan Selar (Selaroides sp.). Penelitian ini dilaksanakan pada bulan September - Oktober 2020 di perairan Kampung Karatung II Kecamatan Manganitu. Teknik pengumpulan data dilakukan dengan wawancara dan observasi terhadap para nelayan. Pendapatan nelayan pancing ulur di Kampung Karatung II yaitu sebesar Rp 1.250.000,- per bulan. Berdasarkan SK Gubernur Sulawesi Utara No. 330 Tahun 2020, upah minimum Provinsi Sulawesi Utara tahun $2020 \mathrm{Rp} 3.310 .723$,- (tiga juta tiga ratus sepuluh ribu tujuh ratus dua puluh tiga rupiah) setiap bulan, dengan demikian pendapatan nelayan di Kampung Karatung II termasuk dalam kategori rendah.
\end{abstract}

Kata kunci: nelayan, pendapatan, pancing ulur, kampung karatung ii, kabupaten kepulauan sangihe

\begin{abstract}
Abtract: This study aims to determine the income of hand line fishermen in Karatung II Village, Manganitu District of Sangihe Islands Regency. Karatung II Village is located in Manganitu District with population of 991 people. The income of fishermen in Karatung II village depends on the catch. The kind of fish caught is Selar (Selaroides sp.). This research was carried out in September to October 2020 in the waters of Karatung II village, Manganitu District. Data collection techniques were carried out by interviewing and observing the fishermen. The income of hand line fishermen in Karatung II Village is Rp. 1,250,000 per month. Based on the Decree of the Governor of North Sulawesi No. 330 of 2020, the minimum wage of North Sulawesi Province in 2020 was IDR 3,310,723 (three million three hundred ten thousand seven hundred and twenty three rupiahs) every month, and therefore, the income of fishermen in Karatung II Village is categorized as a low income.
\end{abstract}

Keywords: fishermen, income, hand line, karatung ii village, sangihe islands regency

\section{PENDAHULUAN}

Pendapatan merupakan penerimaan bersih seseorang (Marini, 2013). Pendapatan nelayan sangat bergantung pada hasil tangkapan (Kusumayanti, dkk., 2018). Jumlah hasil tangkapan merupakan faktor utama dalam menentukan pendapatan nelayan, dimana besarnya pendapatan menentukan tingkat kesejahteraan keluarga (Sukmawardhana, dkk., 2013).
Pancing ulur (hand line) mempunyai penamaan yang berbeda pada setiap daerah, bergantung pada jenis ikan hasil tangkapan, pengunaan umpan alami atau buatan, dan lain-lain. Pancing ulur umumnya digunakan oleh nelayan tradisional untuk menangkap ikan. Pancing ulur dioperasikan dengan cara mengulur dan menunggu hingga umpan pancing dimakan oleh ikan dan ikan tertangkap, selanjutnya pancing diangkat 
ke perahu, demikian seterusnya (Tamarol \& Sarapil, 2018). Usaha penangkapan ikan dengan menggunakan pancing ulur merupakan usaha masyarakat nelayan tradisional dengan peralatan sederhana dan ramah lingkungan (Wagiu, 2009 dalam Pratama, dkk., 2012).

Kampung Karatung II terletak di Kecamatan Manganitu, berhubungan erat dengan Kampung Karatung I karena awalnya merupakan satu kampung dan satu pemerintahan, Namun, demi kemudahan pelayanan pemerintah, kampung dimekarkan menjadi Kampung Karatung I dan Kampung Karatung II. Pada Gambar 1, dapat dilihat bahwa sebagian besar penduduk di Kampung Karatung II memiliki pekerjaan sebagai petani yaitu sebesar 40,94 \%. Sedangkan, penduduk yang bekerja sebagai nelayan mempunyai persentase sebesar $19,38 \%$.

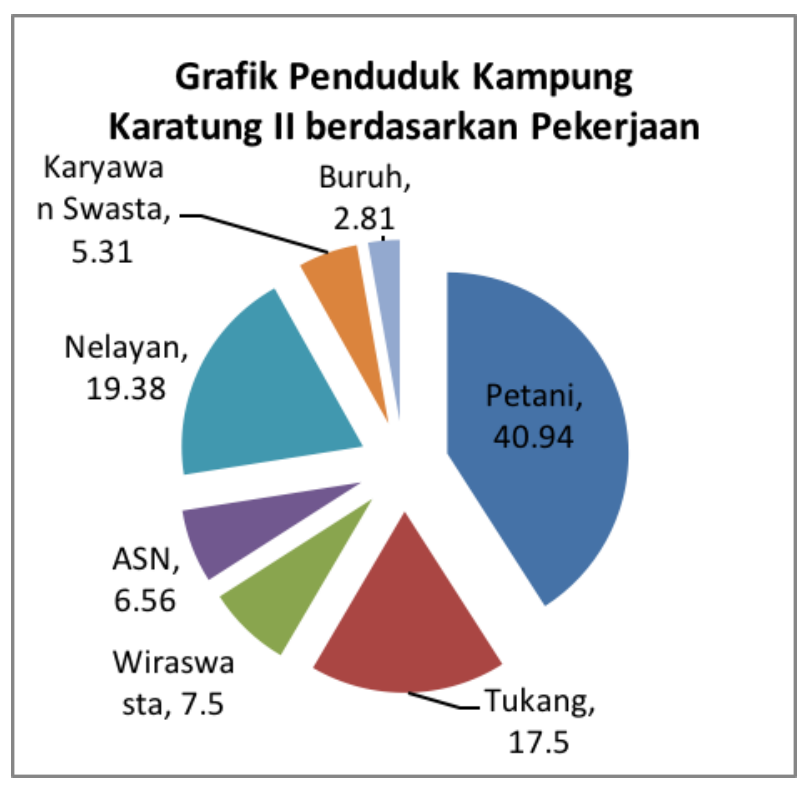

Gambar 1. Grafik Penduduk Kampung Karatung II berdasarkan pekerjaan.

Pendapatan nelayan di Kampung Karatung II bergantung pada hasil tangkapan. Jenis ikan hasil tangkapan pada umunya yaitu ikan Selar (Selaroides sp.). Ada juga pancing ulur yang digunakan untuk menangkap Tuna (Thunnus sp.). Menurut Wafi, dkk., (2019), tingkat kesejahteraan nelayan di Selat Sunda termasuk dalam kategori tinggi $(56,67 \%)$ dan sedang $(43,33 \%)$, dimana nelayan dengan tingkat kesejahteraan tinggi merupakan nelayan pada kapal skala besar (> 10 GT) dan bertugas sebagai nakhoda dan juru kapal. Menurut Triyanti \& Firdaus (2016), nelayan skala kecil di Kabupaten Indramayu memiliki tingkat kesejahteraan yang rendah. Penelitian ini bertujuan untuk melihat besarnya pendapatan nelayan pancing ulur di Kampung Karatung II Kecamatan Manganitu.

\section{METODE PENELITIAN}

Penelitian ini dilaksanakan pada bulan September sampai dengan Oktober 2020 di Kampung Karatung II Kecamatan Manganitu. Alat - alat yang digunakan yaitu alat tulis - menulis untuk mencatat informasi dari nelayan, mistar untuk mengukur panjang ikan, dan kamera (handphone) untuk mendokumentasikan kegiatan penelitian.

Teknik pengumpulan data dilakukan dengan wawancara dan observasi terhadap para nelayan.

Menurut Pratama, dkk., (2012), teknik analisis pendapatan nelayan dilakukan dengan perhitungan sebagai berikut.

$\pi=T R-T C$

dimana:

$\pi=$ pendapatan keuntungan (Rp per tahun),

$\mathrm{TR}=$ Total Penerimaan,

TC $=$ Total Biaya

Kemudian, hasil yang diperoleh dianalisis dengan metode deskriptif kualitatif, dimana menuturkan dan menafsirkan data secara sistematis, faktual dan akurat, serta mengangkat fakta, variable, dan fenomenafenomena yang terjadi pada saat itu (Sugiyono, 2003 dalam Pratama, dkk., 2012).

\section{HASIL DAN PEMBAHASAN}

Kampung Karatung II terletak di Kecamatan Manganitu dengan jumlah penduduk 991 jiwa. Batas batas wilayah Kampung Karatung II yaitu sebagai berikut.

- Utara : Kampung Karatung I

- Timur : Kampung Karatung I

- Selatan : Kampung Kauhis 
- Barat : Laut Sulawesi

Pada Gambar 2, dapat dilihat bahwa sebagian besar penduduk di Kampung Karatung memiliki tingkat pendidikan SD, dengan persentase sebesar $41,50 \%$. Kemudian, diikuti dengan SMA sebesar $33,09 \%$. Dan yang paling rendah adalah tingkat pendidikan D3/ S1 dengan persentase sebesar 4,02\%.

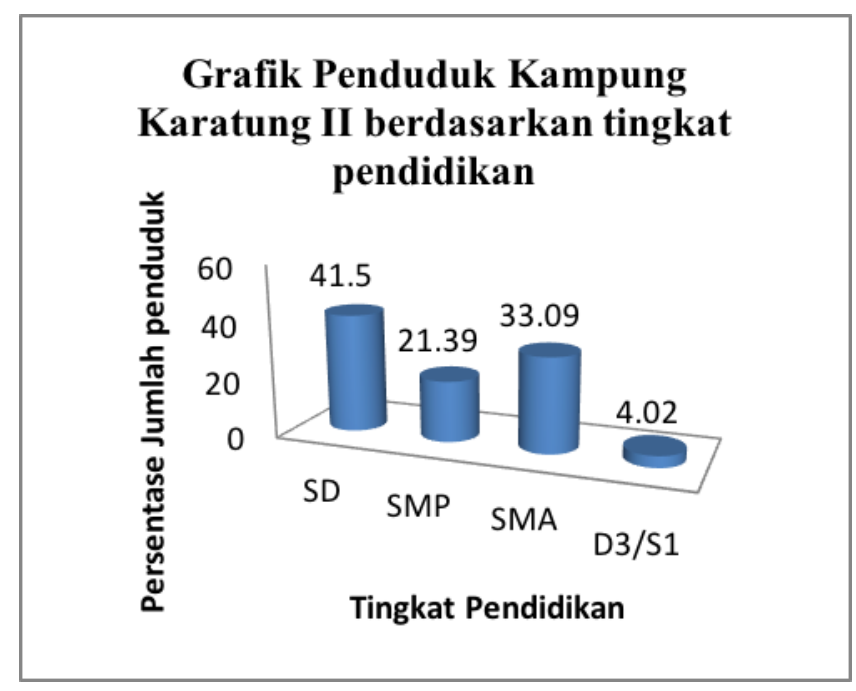

Gambar 2. Grafik Penduduk Kampung Karatung II berdasarkan tingkat pendidikan.

Gambar 3 menunjukkan sebagian besar penduduk di Kampung Karatung II memeluk agama Kristen Protestan dengan persentase sebesar 93,04\%, dan penduduk lainnya menganut agama Katholik dengan persentase sebesar $6,96 \%$.

\section{Grafik Penduduk Kampung Karatung II berdasarkan Agama}

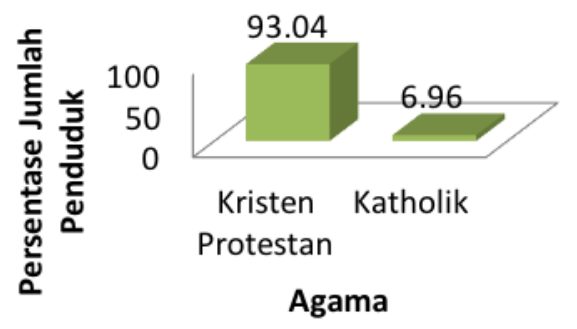

Gambar 3. Grafik penduduk Kampung Karatung II berdasarkan Agama.

Menurut Rosni (2017), nelayan tradisional merupakan orang yang menggantungkan hidupnya pada kegiatan penangkapan ikan di laut dan bergantung pada cuaca. Nelayan di Kampung Karatung II menggantungkan hidup mereka pada kegiatan penangkapan ikan dengan menggunakan alat tangkap tradisional yaitu pancing ulur. Alat tangkap pancing ulur yang digunakan oleh nelayan di Kampung Karatung II memiliki konstruksi sebagai berikut.

a) Penggulung tali, terbuat dari kayu, yang berfungsi untuk menggulung tali agar dapat dioperasikan dengan mudah.

b) Tali utama berbahan Polyamide (PA) monofilament No. 50 dengan panjang 35 meter, berfungsi sebagai tempat untuk mengikat tali cabang.

c) Tali cabang terbuat dari bahan PA monofilament No. 40 dengan panjang $5 \mathrm{~cm}$. jumlah tali cabang yang terikat pada tali utama adalah 20 buah.

d) Mata pancing terbuat dari besi dengan ukuran No. 19.

e) Pemberat terbuat dari besi dengan berat 200 gram.

f) Umpan terbuat dari karet berwarna merah (karet pentil).

g) Kili - kili terbuat dari besi No. 5 .

Sketsa pancing ulur yang digunakan nelayan di Kampung Karatung II ditunjukkan pada Gambar 4. 


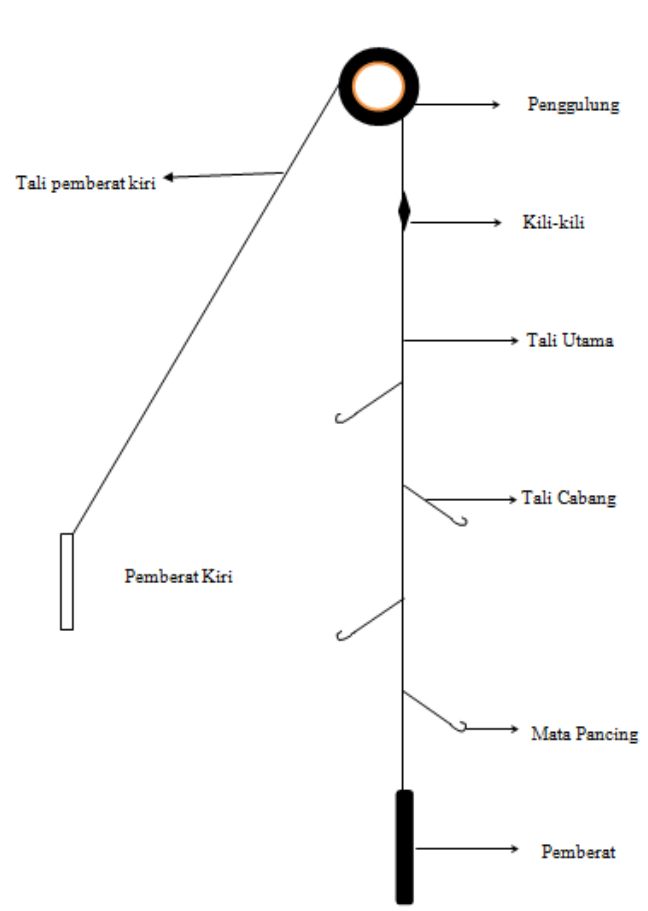

Gambar 4. Sketsa Pancing Ulur di Kampung Karatung II.

Biaya tetap dalam usaha penangkapan ikan bagi nelayan di Kampung Karatung yaitu biaya yang digunakan untuk membeli perahu, cool box, serta alat tangkap pancing ulur. Sedangkan, biaya variabel atau biaya operasional yang dikeluarkan oleh nelayan per trip ditunjukkan pada Tabel 2 di bawah ini.

Tabel 2. Biaya Operasional per trip.

\begin{tabular}{llrcr}
\hline No. & Bahan & Jumlah & Satuan & Biaya (Rp) \\
\hline 1 & Es & 5 & Buah & 10.000 \\
\hline 2 & Bensin & 2 & Liter & 20.000 \\
\hline 3 & Rokok & 1 & bungkus & 20.000 \\
\hline \multicolumn{5}{c}{ Total } \\
\hline
\end{tabular}

Rata-rata hasil tangkapan yang diperoleh adalah 150 ekor per trip. Dari hasil tangkapan ini, ada yang dijual, ada yang dibagi ke keluarga dan tetangga. Biasanya yang dijual sebanyak 2/3 bagian, atau 100 ekor dengan harga jual per 6 -7 ekor adalah sebesar Rp 20.000. Dengan demikian, maka hasil penjualan ikan yang diperoleh adalah sebesar Rp 300.000 . Keuntungan yang diperoleh nelayan per trip adalah $\mathrm{Rp}$ 300.000 dikurangi Rp.50.000, atau sebesar Rp 250.000,-. Nelayan menangkap ikan pada saat fase "bulan baru". Fase bulan baru terjadi sekali dalam 29 hari atau 29,5 hari. Pada minggu terjadinya fase bulan baru, nelayan menangkap ikan sebanyak 5 kali trip. Sehingga, pendapatan nelayan dalam 1 bulan $=\mathrm{Rp}$ 250.000 x $5=\operatorname{Rp} 1.250 .000$. Berdasarkan $\mathrm{SK}$ Gubernur Sulawesi Utara No. 330 Tahun 2020, upah minimum Provinsi Sulawesi Utara Tahun 2020 adalah sebesar Rp 3.310.723 (tiga juta tiga ratus sepuluh ribu tujuh ratus dua puluh tiga rupiah) setiap bulan, dan dengan demikian tingkat kesejahteraan nelayan di Kampung Karatung II masih tergolong rendah. Menurut Lubis \& Sembiring (2017), masyarakat pesisir yang sebagian besar bekerja sebagai nelayan mempunyai tingkat kesejahteraan relatif masih rendah. Hal ini senada juga dengan hasil penelitian Hendrik (2011), dimana kisaran pendapatan nelayan dengan menggunakan sampan yaitu sebesar $\mathrm{Rp}$ 1.000.000 sampai dengan Rp 2.000.000, dengan pendapatan ratarata sebesar Rp 1.582.833 per bulan. Menurut Syahma (2016), lama melaut dan ukuran mesin merupakan faktor yang memiliki pengaruh signifikan terhadap pendapatan nelayan. Hal ini juga didukung oleh Timotius (2016) bahwa pengalaman melaut, modal kerja dan tenaga kerja berpengaruh signifikan terhadap kegiatan produksi penangkapan ikan. Sehingga, penting juga bagi pemerintah untuk memfasilitasi pengadaan modal bagi para nelayan.

\section{KESIMPULAN}

Besarnya pendapatan nelayan pancing ulur di Kampung Karatung II yaitu sebesar Rp 1.250.000 per bulan, dan termasuk dalam kategori rendah. Pemerintah perlu memfasilitasi nelayan dengan pengadaan modal.

\section{DAFTAR RUJUKAN}

Hendrik. 2011. Analisis Pendapatan dan Tingkat Kesejahteraan Masyarakat Nelayan Danau Pulau Besar dan Danau Bawah di Kecamatan Dayun Kabupaten Siak Propinsi Riau. Jurnal Perikanan dan Kelautan, 16(1): 21 - 32 
Kusumayanti, N. M. D., Setiawina, I N. D., \& Utama, I M. S. 2018. Analisis Faktor - faktor yang Mempengaruhi Kesejahteraan Nelayan di Kabupaten Jembrana. Jurnal Buletin Studi Ekonomi, 23(2): $251-268$

Lubis, A. I. F., \& Sembiring, R. 2017. Analisis Peningkatan Kesejahteraan Nelayan dalam Mendukung Pembangunan dan Menurunkan Angka Kemiskinan di Wilayah Pesisir Kabupaten Batu Bara. Forum Ekonomi dan Sosial ke-1, Ikatan Sarjana Ekonomi Indonesia Cabang Semarang.

Marini, R. 2013. Analisis Pendapatan Rumah Tangga Nelayan di Kecamatan Kuala Pesisir Kabupaten Nagan Raya. Skripsi. Program Studi Agribisnis Fakultas Pertanian Universitas Teuku Umar Meulaboh, Aceh Barat.

Pratama, D. S., Gumilar, I., \& Maulina, I. 2012. Analisis Pendapatan Nelayan Tradisional Pancing Ulur di Kecamatan Manggar, Kabupaten Belitung Timur. Jurnal Perikanan dan Kelautan, 3 (3): 107 - 116

Rosni. 2017. Analisis Tingkat kesejahteraan Masyarakat Nelayan di Desa Dahari Selebar Kecamatan Talawi Kabupaten Batubara. Jurnal Geografi, 9(1): 53 - 66

Sukmawardhana, N., Bambang, A. N., \& Rosyid, A. 2013. Analisis Tingkat Kesejahteraan Nelayan Alat Tangkap Gill Net Desa Asinan Kecamatan Bawen Kabupaten Semarang. Journal of Fisheries Resources Utilization Management and Technology, 2(4): $40-49$

Surat Keputusan Gubernur Sulwesi Utara Nomor 330 Tahun 2020 tentang Penetapan Upah Minimum Provinsi Sulawesi Utara Tahun 2021.

Syahma, A. 2016. Analisis Faktor - faktor yang Mempengaruhi Pendapatan Nelayan di Desa Galesong Kota Kecamatan Galesong Kabupaten
Takalar. Skripsi. Program Studi Ekonomi Pembangunan Fakultas Ekonomi Universitas Negeri Makassar.

Tamarol, J., \& Sarapil, C. I. 2018. Kajian Sosial Ekonomi Rumah Tangga Nelayan Pancing Ulur (Hand line) Perorangan di Kecamatan Tabukan Utara Kabupaten Sangihe. Jurnal Ilmiah Tindalung, 4(2): $89-98$

Timotius, D. R. 2016. Analisis Tingkat Kesejahteraan Nelayan di Kampung Nelayan Muara Angke DKI Jakarta. Skripsi. Program Studi Ekonomi Pembangunan Departemen Ekonomi Pembangunan Fakultas Ekonomi Universitas Sumatera Utara Medan

Triyanti, R. \& Firdaus, M. 2016. Tingkat Kesejahteraan Nelayan Skala Kecil dengan Pendekatan Penghidupan Berkelanjutan di Kabupaten Indramayu. Jurnal Sosek KP, 11(1): $29-43$

Wafi, H., Yonvitner, \& Yulianto, G. 2019. Tingkat Kesejahteraan Nelayan dari Sistem Bagi Hasil di Selat Sunda. Jurnal Pengelolaan Perikanan Tropis, 3(2): $1-8$ 